\title{
Antioxidant Activity of Endophytic Bacterial Extract Isolated from Clove Leaf (Syzygium aromaticum L.)
}

\author{
Widya Triandriani ${ }^{1}$, Dina Dyah Saputri ${ }^{2}$, Usep Suhendar ${ }^{3}$, Sogandi 1 * \\ ${ }^{1}$ Department of Pharmacy, Faculty of Pharmacy, University of 17 Agustus 1945, Jakarta, Indonesia \\ ${ }^{2}$ Faculty of Teacher and Training Education, University of Pakuan, Bogor, Indonesia \\ ${ }^{3}$ Department of Pharmacy, Faculty of Pharmacy, University of Pakuan, Bogor, Indonesia
}

Article history:

Submission January 2020

Revised February 2020

Accepted May 2020

*Corresponding author:

E-mail:

sogandi@uta45jakarta.ac.id

\begin{abstract}
Clove (Syzygium aromaticum L.) is one type of spice plant that has high antioxidant content because of the high eugenol compounds. However, isolating these bioactive compounds require a significant amount of biomass. A known alternative solution to overcome the problems is through the utilization of endophytic bacteria in clove leaves. Endophytic cloves leaf bacteria can be a good antioxidant resource. Endophytic bacteria are bacteria that grow in plant tissues that is not pathogenic, which can replace these plants. The aim of this study is isolating endophytic bacterial from clove leaves, screening endophytic bacteria, determining potential endophytic bacteria as producer antioxidant compounds, and identifying potential isolate using $16 \mathrm{~S}$ rRNA. This study used endophytic bacteria isolated from clove leaves (Syzygium aromaticum L.). Antioxidant activity determined using DPPH method. It was founded 7 isolates of endophytic bacteria namely WDY1, WDY2, WDY3, WDY4, WDY5, WDY6, and WDY7. The isolate WDY6 shows the highest antioxidant activity. WDY6 isolate is identical to Staphylococcus sp. with a $100 \%$ similarity. Staphylococcus sp. has the highest antioxidant activity in the stationary phase. The content of chemical compounds from WDY6 isolates is pyrazine that belongs to alkaloids.
\end{abstract}

Keywords: Antioxidants, isolation, endophytic bacteria, DPPH

\section{Introduction}

Plants are one of the most important natural resources in the treatment efforts to maintain health in the community. People still often use traditional medicines derived from medicinal plants. Medicinal plants are plants that have medicinal properties and are used as medicine in healing and preventing diseases. Understanding the efficacy of drugs is to contain active substances that function to treat certain diseases or if they do not contain certain active substances but contain the resultant or synergy effect of various substances that function to treat.

Indonesia is one of the countries known for its natural wealth because it has various types of plants that can be medicinal. Natural re- sources have provided the pharmaceutical industry with the most important sources of lead compounds and up to $40 \%$ of modern drugs are derived from natural sources (Jassim \& Naji, 2003). This suggests a potential therapeutic role of plants in human health (Barthwal et al., 2008). Plants against chronic oxidative stress-related disease because contain chemical families and the number of antioxidants (Asif, 2015). Natural antioxidants such as tocopherol, ascorbic acid, and flavonoids have been widely studied in the fields of medicine and pharmacology because of their activities as antitumor, antimutagenic, anticancer, and other diseases (Birch et al., 2001).

Clove (Syzygium aromaticum L.) is one type of spice plants that has high antioxidant activ- 
ity due to the high content of eugenol. The essential oil in clove flower buds (Eugeniacaryophylus) is used as a local anesthetic (Khalaf et al., 2018). Clove contains several phenol components, namely ( $\left.\mathrm{C}_{10} \mathrm{H}_{12} \mathrm{O} 2\right)$, acetyl eugenol, $\mathrm{a}$ and $\mathrm{b}$ caryofelin, eugenia (eugenol isomer), vanillin, and galanin acid. Eugenol has an antioxidant activity which has the same effect as $\alpha$-tocopherol in inhibiting lipid peroxidation, LDL oxidation, and very low density lipoproteins (VLDL) (Ogata et al., 200). Plant phenols are one of the largest groups that act as antioxidant compounds, both in leaves, flowers, and roots (Pourmorad et al., 2006). Eugenol is a phenol compound that can be isolated from the leaves, stems and flower buds, but the cheapest and most economical are those derived from cloves leaf oil. Eugenol content in leaves is around $70-\%-80 \%$ and cloves leaf oil derived from Zanzibar type. Clove has the highest eugenol content especially in young and old leaves (Barbara \& Christine, 2006).

Endophytic bacteria live in the vascular tissue of plants without causing negative effects. The symbiotic relationship of mutualism between bacteria and plants allows bacteria to produce the same bioactive compounds as those contained in their host plants (Barbara \& Christine, 2006). The endophytic microorganism is a microorganism that can be extracted from the inside of plants or isolated from seeds, root, stems, and twigs, and bark from various types of plants (Larran et al., 2016). Antioxidants are compounds that are able to eliminate, cleanse, resist the formation of reactive oxygen and free radicals in the body. Free radicals are unstable atoms or molecules because they do not have unpaired electrons in their outer orbitals so it is very reactive to get electron pairs by binding to body cells. If this happens continuously it can cause cell damage and death (Anita et al., 2015). The main function of antioxidants is used to reduce the oxidation process of fats and oils, reduce the occurrence of the process of damage in food, prolong the period of use in the food industry, increase the stability of fats contained in food. Antioxidants are not only used in the food industry, the petroleum industry, the rubber industry and so on (Sahu et al., 2013).

On the contrary, metabolites of Syzygium aromaticum reported have low riboflavin (1.5 $\mu \mathrm{g} / \mathrm{g})$ content but high ascorbate $(985.6 \mu \mathrm{g} / \mathrm{g})$ and tocopherol $(660.6 \mu \mathrm{g} / \mathrm{g})$ content (Larran et al., 2016). This study was aimed to isolate endophytic bacteria, identify endophytic bacteria from clove (Syzygium aromaticum) leaves, to know the antioxidant activity, and analyze antioxidant components produced by potential endophytic bacterial isolates.

\section{Material and Methods \\ Isolation of Endophytic Bacteria}

In this study, clove (Syzygium aromaticum L.) leaves with characteristic good condition and from the middle grow of the stem were surface-sterilized following the protocol by Sogandi et al., (2019) with modification. At first fresh leaves were washed with running tap water, then surface sterilized with $2 \%$ sodium hypochlorite for $5 \mathrm{~min}$ and washed with distilled water at least three times. The clove leaves sample finally washed with $70 \%$ ethanol and then evaporated. After evaporation of ethanol from the Clove leaves the surface, they were cut into small pieces $(1 \times 1 \mathrm{~cm})$ and placed on the surface of Tryptone Soy Agar (TSA) plates supplemented with nystatin and incubated at 37 ${ }^{\circ} \mathrm{C}$. The plates were checked each day after inoculation and after 3 days of incubation, the endophytic bacteria from clove leaves sample was taken 7 colonies with the best morphology, purified with reculture isolate to make sure that's literally single colony, numbered isolates are WDY1, WDY2, WDY3, WDY4, WDY5, WDY6, and WDY7, transferred separately to TSA slant as culture stock and kept at $4{ }^{\circ} \mathrm{C}$ for further use.

\section{Preparation of Bacterial Culture}

Ten micro-liter isolates obtained were transferred to reaction tubes containing $50 \mathrm{~mL}$ of TSB medium. The isolate was incubated for $24 \mathrm{~h}$ at $37^{\circ} \mathrm{C}$. Cultures that have been incubated are transferred to the centrifuge by a centrifugation process to separate the pellets from the supernatant. The culture was centrifuged at $6000 \mathrm{rpm}$ for 20 minutes. The obtained super- 
natant is stored at $-20^{\circ} \mathrm{C}$. Next, the supernatant was measured for its antioxidant activity. Measurements are only made in culture supernatants because the highest antioxidant activity is found in supernatants.

\section{DPPH Radical Scavenging Assay}

The antioxidant activity of the extracts was measured on the basis of the scavenging activity of the stable 1,1- diphenyl 2- picrylhyorazyl (DPPH) free radical. As much as $0.5 \mathrm{~mL}$ of 100 ppm DPPH solution in $1 \mathrm{~mL}$ methanol was mixed with $0.5 \mathrm{~mL}$ of plant extract. The mixture was shaken vigorously and allowed to stand at room temperature for $30 \mathrm{~min}$. then, absorbance was measured at $517 \mathrm{~nm}$ using a spectrophotometer (UV-VIS, Shimadzu). The reference standard compound being used as ascorbic acid. The $\mathrm{IC}_{50}$ value of the sample, which is the concentration of the sample required to inhibit $50 \%$ of the DPPH free radical, was calculated using the Log dose inhibition curve. Lower absorbance of the reaction mixture indicated higher free radical activity (Sahu et al., 2013).

\section{Growth Curve Optimization}

Growing potential isolates in $5 \mathrm{~mL}$ TSB medium then incubated overnight. Isolates potential was grown on TSB medium as much as 250 $\mathrm{mL}$. Then taken $1 \%$ and then cultured, the potential isolate was incubated at $37{ }^{\circ} \mathrm{C}$ for $24 \mathrm{~h}$. every $2 \mathrm{~h}$ isolate culture was taken and transferred to sterile $2 \mathrm{~mL}$ micro-chemicals and stored at $-20{ }^{\circ} \mathrm{C}$. The isolated culture read its absorption value at a wavelength of $600 \mathrm{~nm}$ then a growth curve was made.

\section{Strain Identification of Potential Isolate with 16S rRNA Analysis}

Strains isolate potential was identified using the 16S rRNA gene. Total genomic DNA was extracted using a manual base on CTAB methods (Sogandi et al., 2019). With genomic DNA as the template, a portion of the bacterial $16 \mathrm{~S}$ rRNA gene $( \pm 1400 \mathrm{bp})$ was amplified using universal primers (27F and 1492R) designed by Jiang et al., (2006). The $25 \mu \mathrm{L}$ of PCR mixture contained $12.5 \mu \mathrm{L}$ Taq Mix $2 \mathrm{x}, 1 \mu \mathrm{L}$ primer forward, $1 \mu \mathrm{L}$ primer reverse, and $1 \mu \mathrm{L}$ of genomic DNA with a concentration around $100 \mathrm{ng} / \mu \mathrm{L}$ as a template, and PCR grade water to make up the

JAAB | Journal of Agriculture and Applied Biology volume. A negative control (PCR mixture without DNA template) was included for each PCR reaction. Amplification was carried out in thermal cycler using the following condition $95{ }^{\circ} \mathrm{C}$ for $3 \mathrm{~min}, 35$ denaturation cycles at $95{ }^{\circ} \mathrm{C}$ for $15 \mathrm{~s}$, annealing temperatures $52^{\circ} \mathrm{C}$ for the $30 \mathrm{~s}$, primer extension $72^{\circ} \mathrm{C}$ for $45 \mathrm{~s}$ and followed by a final extension at $72{ }^{\circ} \mathrm{C}$ for $3 \mathrm{~min}$. The sequencing process was made at Macrogen, Korea. Furthermore, sequence of DNA was edited using ChromasPro software, alignment sequence by DNA MAN v9.0 software, aligned with the sequences in the NCBI Gene Bank by basic local alignment search tool (BLAST) program to reveal the sequence homology with a closely related organism, and $16 \mathrm{~s} \mathrm{r}$ R A sequence of potential endophytes WDY6 were deposited in GenBank. Phylogenetic analysis using MEGA 7.0 software to determine the level of genetic relationship. This study used neighbor-joining for statistical method, a bootstrap method for a test of phylogeny with the number of bootstrap replications was 1000 . The phylogenetic analysis was constructed using the MEGA 7.0 software package with modification (Tamura et al., 2011).

\section{GCMS Analysis of Antioxidant Compound}

Extract of secondary metabolite bacteria potential was isolated dissolved with acetone for the determination of bioactive compounds as antioxidant agents. Chemical analysis was conducted using gas chromatography coupled with mass spectrometry (GCMS Agilent Technologies 7890) equipped with the HP ultra 2 Capillary Column $(30 \mathrm{~m} \times 0.20 \mathrm{~mm}$ LD, 0.11 $\mu \mathrm{m}$ film thickness). The column temperature, $250{ }^{\circ} \mathrm{C}$, carrier gas helium linear gas velocity, 30 $\mathrm{cm} / \mathrm{sec}$, split ratio, $1 / 30$, ion source temperature, $230^{\circ} \mathrm{C}$, and interface temperature $280{ }^{\circ} \mathrm{C}$. The identification of chemicals was performed in comparison with the database and confirmed using authentic standard samples (Suhendar \& Sogandi, 2019).

\section{Results and Discussion \\ Isolation of Endophytic Bacteria from Clove Leaves (Syzygium gromaticum L.)}

Isolation of endophytic bacteria from Clove leaves (Syzygium aromaticum L) samples begins with a method of surface sterilization. The 
surface sterilization method is used to remove epiphytic microorganisms that are attached to plant samples. The addition of sodium hypochlorite $(\mathrm{NaOCl})$ is used for surface sterilization which is bactericidal and virucidal (Zinniel et al., 2002; Bolfoni et al., 2014). Seven isolated endophytic bacteria were selected based on morphological characteristics WDY1, WDY2, WDY3, WDY4, WDY5, WDY6, and WDY7. This result is consistent with Lodewyckx et al. (2002) which argue that endophytic bacteria can be isolated from the roots, leaves, stems, flowers, fruits, and seeds.

The diversity of endophytic bacteria is determined by the condition of plants as host plants for endophytic bacteria. This explains that physiological factors that influence the growth of host plants also affect the diversity of endophytic bacteria. Physiological factors include soil structure, plant age, geographical distribution, time of sampling, and types of plant tissue (Zinniel et al., 2002).

\section{Antioxidant Activity of Endophytic Bacterial}

The antioxidant activity test of endophytic bacteria isolates was carried out by the DPPH method. WDY6 isolate is the most potential isolate because it has antioxidant activity with the highest inhibitory value. The results of the measurement of antioxidant activity of Clove leaves (Syzygium aromaticum L) endophytic bacteria isolates shown in Table 1.

The antioxidant measurement result using DPPH method showed that the WDY6 isolate has highest acyvity. WDY6 isolate had inhibition of $68.90 \%$. Vitamin C (ascorbic acid) as a positive control with a concentration of 100 ppm has inhibition of $87.92 \%$. The antioxidant activity of DPPH Clove leaves (Syzygium aromaticum $L$ ) extracts is depends on the solvent used in the extraction. There is a correlation between antioxidant activities with a total phenolic compound. The polyphenol compounds such as quercetin and kaempferol should exist in the leaves. Methanol is the polar solvent which can pull out more polyphenol compounds. The previous study reported that methanol extract of $C$. spinosa buds showed the result of rich in flavonoids including several quercetins and kaempferol glycosides. They demonstrated to possess strong antioxidant or free radical scavenging effectiveness. Vitamin C (ascorbic acid) used as a positive control in this study. Motlhanka, Habtemariam \& Houghton (2008) revealed that ascorbic acid is widely used because it is seen as being safe and causing few adverse effects.

Table 1. The results of the measurement of antioxidant activity of Clove leaves (Syzygium aromaticum L) endophytic bacteria isolates

\begin{tabular}{cc}
\hline Sample & $\begin{array}{c}\text { Average Inhibition (\%) } \\
\pm \text { standard deviation (SD) }\end{array}$ \\
\hline WDY1 & $59.20 \pm 0.94$ \\
WDY2 & $31.59 \pm 0.78$ \\
WDY3 & $39.92 \pm 0.75$ \\
WDY4 & $45.14 \pm 0.38$ \\
WDY5 & $63.80 \pm 0.65$ \\
WDY6 & $68.90 \pm 0.94$ \\
WDY7 & $55.84 \pm 0.63$ \\
Vit.C & $87.92 \pm 0.63$ \\
\hline
\end{tabular}

Studies on medicinal plants or herbs with high phenolic contents have gained importance over the past few years due to the high antioxidant, anti-carcinogenic activities, anti-inflammatory and are of great value in decreasing the risk of many human diseases (Demla \& Verma, 2012). The antioxidative activities observed can be attributed to either the different mechanisms exhibited by different polyphenolic compounds that are tocopherols, flavonoids 
and other organic acids and to the synergistic effects of different compounds. Many studies have shown that many polyphenols contribute significantly to the antioxidant activity and act as highly effective free radical scavengers which is mainly due to their redox properties, which can play an important role in absorbing and neutralizing free radicals, quenching singlet and triplet oxygen or decomposing peroxides (Rojas et al., 2014).

Clove leaves (Syzygium aromaticum L) have the antioxidant activity of eugenol. Eugenol allows the donation of a hydrogen atom and subsequent stabilization of the phenoxil radical generated forming stable compounds that do not start or propagate oxidation. The eugenol molecule possesses an interesting conjugation of the carbon chain with the aromatic ring which could participate in the stabilization of the phenoxyl radical by resonance. This chromophoric system is also present in a molecule of resveratrol which is another important antioxidant (Chaieb et al., 2007).

In addition, this remarkable antioxidant capacity of Clove could be attributed to the higher content of phenolic components such as eugenol and eugenol acetate and to their hydrogen donating ability by which they are considered to be potent free radical scavengers (Stanbury et al., 2016).

\section{Growth Curve Optimization of WDY6 Isolate}

Based on the results, measurement of cell density and antioxidant compound production can be seen that the potential endophytic bacteria WDY6 beginning of the log phase at 0 to 6 hours, this can be seen from the increase in absorbance that is not too high. After the log phase, WDY6 isolate experiences an exponential phase which can be seen by increasing the absorbance value from the $8^{\text {th }}$ till $28^{\text {th }}$ hour. After that, the WDY6 isolate experience stationary phase which can be seen in the absorbance value at the $8^{\text {th }}$ till $36^{\text {th }}$ hour.

Based on the result, secondary metabolites WDY6 isolate was produced after incubation at least 28 hours due to secondary metabolites are commonly produced in the late growth phase. Stanbury, Whitaker \& Hall (2016) revealed that each phase of bacterial growth will affect the number of metabolic products. A primary metabolite is produced in the exponential phase, whereas secondary metabolites are produced in the stationary phase (Sogandi \& Nilasari, 2019). Endophytic bacteria begin producing active compounds after entering the stationary phase. This result also supported Sogandi, Mustofa, Artike, \& Bugi (2015) that bacterial activity can be detected in mid growth exponential phase and quickly reach maximum in the initial stationary phase. The death phase of WDY6 isolate began to be seen at $56^{\text {th }}$ hour after incubation because, at the $56^{\text {th }}$ hour, the results of the isolate absorbance showed the lowest value.

\section{Molecular Identification of Endophytic Bac- terial WDY6 Isolate}

From totally were seven isolates, WDY6 isolate was selected as potential isolates. Furthermore, isolation of the genome from this isolate was carried out. The isolate genome was amplified using the $16 \mathrm{~S}$ rRNA gene using a PCR machine. PCR results were then electrophoresed using $0.8 \%$ agarose gel at 100 volts for 60 minutes. Agarose gel was then visualized under UV light and DNA bands were obtained on the gel with a size of $\pm 1500 \mathrm{bp}$ (Figure 1).

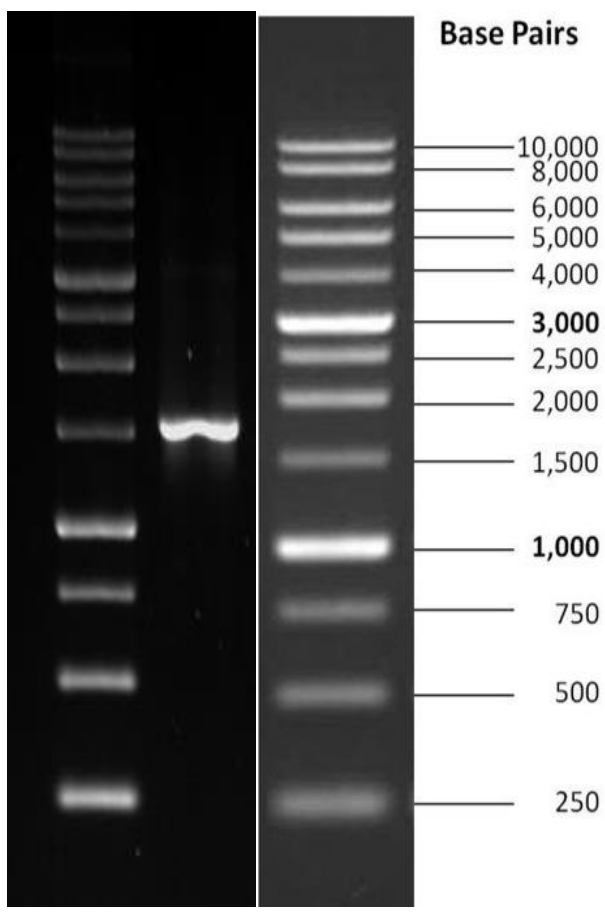

Figure 1. Gel electrophoresis of PCR product 16s rRNA gene amplification 
After purification, the 16S rRNA gene sequence was determined. The partial sequences of 16S rRNA obtained are aligned with the sequences of bases in the NCBI database. Sequencing of WDY6 isolate that has been aligned shows that the 16S rRNA gene in the isolate is $\pm 1500 \mathrm{bp}$ (base pair). Furthermore, the 16s rRNA gene sequence of WDY6 isolate was registered to the Genbank NCBI database as Staphylococcus epidermidis. This supported by the reconstruction of phylogenetic trees to determine the relationship between species (Zhang et al., 2019). Bacterial sequence alignment with several other bacterial sequences taken from the NCBI GenBank database is done using clustal X2. In addition, the alignment results were entered into NJPlot to reconstruct phylogenetic trees. The results of phylogenetic tree reconstruction showed that WDY6 isolate had the closest relationship with Staphylococcus epidermidis identify of similarity $100 \%$ (Figure 2).

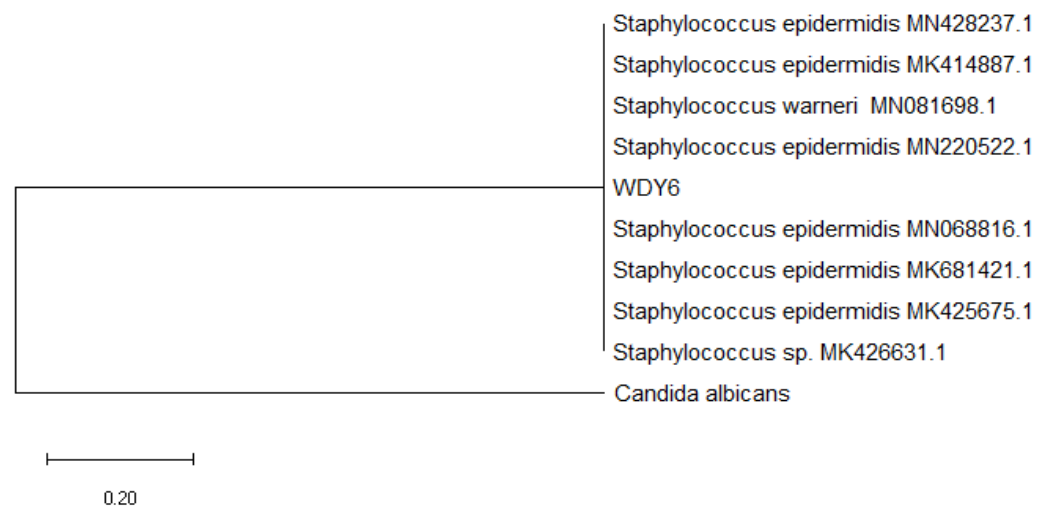

Figure 2. Cladogram resulted of 16s rRNA sequence of potential isolate WDY6 and its allied taxa

Phylogenetic is a method used in systematics to understand the diversity of living things through the reconstruction of kinship relations (phylogenetic relationship). The phylogenetic tree is a graph used to describe the kinship consisting of a number of points and branches with only one branch connecting the two closest points. Each point represents the taxonomic units and each branch represents the relationships between units that describe the hereditary relationship with the ancestors (Harris et al., 2002).

Staphylococcus are Gram-positive bacteria, with diameters of $0.5-1.5 \mu \mathrm{m}$ and characterized by individual coccus, which divides in more than one plane to form grape-like clusters (Candrawati et al., 2018). The Staphylococcus are non-motile, non-spore forming facultative anaerobes that grow by aerobic respiration or by fermentation. Most species have a relative complex nutritional requirement, however, in general, they require an organic source of nitrogen, supplied by 5 to 12 essential amino ac- ids, e.g. arginine, valine, and B vitamins, including thiamine and nicotinamide (Khianngam et al., 2013).

In addition to biologically active secondary metabolites, bacterial endophytes also produce important antimicrobial enzymes. In a study looking for high producing enzyme endophytes, in the mangrove in Thailand, Khianngam et al. (2013) found that Gram-positive bacteria showed more hydrolytic activity compared with that of Gram-negative ones. Unexpectedly, specific strains of $S$. epidermidis were observed to produce a nucleobase analog with the capacity to inhibit DNA synthesis. When administered intravenously or topically applied to mice, this molecule or the live S. epidermidis strain itself suppressed tumor growth in vivo Nakatsuji et al., 2018). Furthermore, Nawangsih, Damayanti, Wiyono, \& Kartika (2011) reported that endophytic bacteria S. epidermidis as biological control of bacterial wilt pathogen (Ralstonia solanacearum) of tomato. 
Identification of Compound Produced by Endophytic WDY6 Isolate

A total of 17 secondary metabolites were identified from WDY6 isolate using GCMS which can be classified into several groups. The compounds with the highest concentration were benzyl hexahydropyrrolo [1,2-a] pyrazine-1,4- dione with a content of $21.48 \%$ at a retention time of 31.309. Our research before has been carried out pyrazine compound also containing on Noni fruits extract with strong antioxidant activity (Sogandi \& Rabima, 2019).

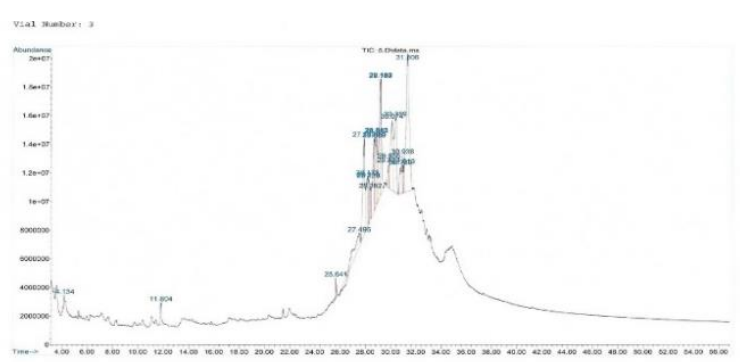

Figure 3. GCMS Spectogram result of secondary metabolite WDY6 isolate
Pyrazine is a compound with nitrogen-containing heterocyclic components and is the result of interactions between $\alpha$ - dicarbonyl while amines are interactions between $\alpha$ amino groups of amino acids. The role of amino acid chains in the formation of pyrazine is important, especially the part of the chain containing nitrogen atoms such as glutamine, asparagine, and lysine (Yulia \& Wijaya, 2015). Pyrazine belongs to an alkaloid compound because it has a nitrogen atom. Alkaloid compounds in WDY6 isolate are thought to have antioxidant content. The presence of 2-Methoxy-5-methyl pyrazine compounds that are as antioxidants. Wang et al. (2014) reported that a new pyrazine derivative was isolated and identified from the fermentation products of Jishengella endophytic 16111 endophytic with mangrove plant, Xylocarpus granatum. In addition, $\beta$-carboline alkaloids exhibited moderate anti-H1N1 virus activity and weak cytotoxicity.

Table 2. GCMS results of secondary metabolite WDY6 isolate

\begin{tabular}{ccc}
\hline RT & Compound & Abundant (\%) \\
\hline 31.309 & $\begin{array}{c}\text { Benzyl Hexahydropyrolol [1,2-A] Pyrazine- } \\
\text { 1,4-dione }\end{array}$ & 21.48 \\
28.172 & 3,5 dihydroxy-4,4 dimethyl-2,5 cyclohexa- & \\
& dien-1-one & 8.91 \\
29.186 & Nitrophenylazo Tert-Butyl Sulfide & 5.76 \\
30.358 & 2-Propylpiperidine & 4.43 \\
\hline
\end{tabular}

\section{Conclusion}

This study revealed endophytic bacteria Staphylococcus epidermidis strain WDY6 was isolated from Syzygium aromaticum L leaves. Secondary metabolite WDY6 show antioxidant activity with $68,90 \%$ inhibition against DPPH free radicals. Furthermore, WDY6 isolate was produced pyrazine as bioactive compounds. Looking at the result of this study, isolate WDY6 can be used as natural resources for medical industries.

\section{Acknowledgment}

Authors would like to thank the Faculty of Pharmacy, University of 17 Agustus 1945, Jakarta, Indonesia, for providing facilities required to carry out this work.

\section{References}

Anita, D., Avtar, S., \& Ritu, M. (2015). Antioxidants of clove (Syzygium aromaticum) prevent metal induced oxidative damage of biomolecules. International Research Journal Pharmaceutical, 6(4), 273-278. doi:10.7897/22308407.06460

Asif, M. (2015). Chemistry and antioxidant activity of plants containing some phenolic compounds. International Scientific Organization Journal, 1(1): 35-52. Retrieved from http://isojournal.com/chemint.

Barbara,J. E. S., \& Christine, J. C. B. (2006). What are endophytes. International Microbial Root Endophytes. (Thomas N. Sieber), Springer-Verlag, Berlin.

Barthwal, J., Nair, S., \& Kakkar, P. (2008). Heavy metal accumulation in medicinal plants collected from environmentally 
different sites. Biomedical Environmental Science, 21, 319324. doi:10.1016/S0895-3988(08)60049-5

Birch, A. E., Fenner, G. P., Watkins, R., \& Boyd, L. C. (2001). Antioxidant properties of evening primrose seed extracts. Journal Agriculture Food Chemistry, 49, 4502-4507. doi:10.1021/if010542f

Bolfoni, M. R., Ferla, M. D. S., Sposito, O. D. S., Giardino, L., Jacinto, R. D. C., Pappen, F. G. (2014). Effect of a surfactant on the antimicrobial activity of sodium hypochlorite solutions. Brazil Dental Journal, 24(5), 416-419. doi: 10.1590/01036440201300049

Candrawati, E., Rupaedah, B., Sumpono., \& Sundaryono, A. (2018). ability of active compound extract of endophytic bacteria to inhibit the growth of Fusarium oxysporum f.sp. in oil palm. Journal of Biotechnology and Biosains, 5(2), 214-221. Retrieved from http://ejurnal.bppt.go.id/index.php/IBBI

Chaieb, K., Zmantar, T., Ksouri, R., Hajlaoui, H., Mahdouani, K., Abdelly, C., \& Bakhrouf, A. (2007). Antioxidant properties of the essential oil of Eugenia caryophyllata and its antifungal activity against a large number of clinical Candida species. Mycoses, 50, 403-406. doi:10.1111/j.14390507.2007.01391.x

Demla, M., \& Verma, H. (2012). Invitro antioxidant activity, total phenolic and total flavonoid content of different extracts of Solanum xanthocarpum berries. International Journal of pharmacy and pharmaceutical sciences, 4, 154-157. Retrieved from https://innovareacademics.in/

Harris, L. G., Foster, S. J., \& Richards, R. G. (2002). An introduction to Staphylococcus aureus, and techniques for identifying and quantifying Staphylococcus aureus adhesins in relation to adhesion to biomaterials: review. European cells and materials, 4, 39-60. doi: 10.22203/ecm.v004a04

Jassim, S. A. A., \& Naji, M. A. (2003). Novel antiviral agents: A medicinal plant perspective. Journal of Applied Microbiology, 95, 412-427. doi: 10.1046/i.1365-2672.2003.02026.X

Jiang, H., Dong, H., Zhang, G., Yu, B., Chapman, L. R., Fields, M. W. (2006). Microbial diversity in water and sediment of lake chaka, an athalassohaline lake in northwestern china. Applied and Environmental Microbiology, 72 (6), 3832-3845. doi: 10.1128/aem.02869-05

Khalaf, N, A., Ashok, K. S., Atif, A. O., Zaha, E. A., \& Husni, F. (2008). Antioxidant activity of some common plants. Turkish Journal Biology, 31, 1-5. Retrieved from http://iournals.tubitak.gov.tr/

Khianngam, S., Techakriengkrai, T., Raksasiri, B. V., Kanjanamaneesathian, M., \& Tanasupawat, S. (2013). Isolation and screening of endophytic bacteria for hydrolytic enzymes from plant in mangrove forest at Pranburi, Prachuap Khiri
Khan, Thailand. in Proceedings of the $5^{\text {th }}$ international symposium on plant protection and plant health, 279-284. Retrieved from https://www.cabdirect.org/cabdirect/abstract/20153047993

Larran, S., Simon, M. R., Moreno, M. V., Siurana, M. P. S., \& Perello, A. (2016). Endophytes from wheat as biocontrol agents against tan spot disease. Biological Control, 92, 17-23. doi: 10.1016/j.biocontrol.2015.09.002

Lodewyckx, C., Vangronsveld, J., Porteous, F., Moore, E. R. B., Taghavi, S., Mezgeay, M., \& Van, D. L. D. (2002). Endophytic bacteria and their potential applications. Critical Reviews in Plant Sciences, 21, 583-606. doi: 10.1080/0735$\underline{260291044377}$

Motlhanka, D. M. T., Habtemariam, S., \& Houghton, P. (2008). Free radical scavenging activity of crude extracts and 4-o-methylepigallocatechin isolated from roots of Cassine transvaalensis. Burtt-davy from Botswana. African Journal of Biomedical Research, 11: 55-63. doi:10.4314/ajbr.v11i1.50667

Nakatsuji, T., Chen, T. H., Butcher, A. M., Trzoss, L. L., Nam, S. J., Shirakawa, K.T., Zhou, W., Oh, J., Otto, M., Fenical, W., Gallo, R. L. (2018). A commensal strain of Staphylococcus epidermidis protects against skin neoplasia. Science Advance, 4(2), 1-9. doi: 10.1126/sciadv.aao4502

Nawangsih, A. A., Damayanti, I., Wiyono, S., \& Kartika, J. G. (2011). Selection and characterization of endophytic bacteria as biocontrol agents of tomato bacterial wilt disease. Hayati Journal of Biosciences, 18(2), 66-70. doi:10.4308/hjb.18.2.66

Ogata, M., Hoshin, M., Rano, S., \& Endo, T. (2000). Antioxidant activity of eugenol and related monomeric and dimeric compounds. Chemistry Pharmaceutical Bulletin, 48, 147149. doi: $10.1248 /$ cpb. 48.1467

Pourmorad, F., Hosseinimehr, S. J., \& Shahabimajd, N. (2006). Antioxidant activity, phenol, and flavonoid contents of some selected Iranian medicinal plants. Africans Journal of Biotechnology, 11, 1142-1145. Retrieved from http://www.academicjournals.org/AJB

Rojas, D. F. C., Souza, C. R. F., \& Oliveira, W. P. (2014). Clove (Syzygium aromaticum): a precious spice. Asian Pacific Journal Tropical Biomedicine, 4(2), 90-96. doi: $\underline{10.1016 / S 2221-1691(14) 60215-X}$

Sahu, R. K., Kar, M., \& Routray, R. (2013). DPPH free radical scavenging activity of some leafy vegetables used by tribals of Odisha, India. Journal of Medicinal Plants Studies, 1 (4), 2127. Retrieved from http://www.plantsjournal.com/

Sogandi \& Rabima, R. ( 2019). Identification of active compound extracts from noni fruit (Morinda citrifolia L.) and its potential as antioxidants (In Indonesian). Jurnal Kimia Sains 
dan Aplikasi, 22(5), 206-212. doi: 10.14710/jksa.22.5.206212

Sogandi, \& Nilasari, P. (2019). Isolation and molecular identification of Endophytic bacteria from Noni fruits (Morinda citrifolia l.) and their antibacterial activity. IOP Conference Series: Earth Environmental Science, 299, 012020. Retrieved from Https://Iopscience.Iop.Org/Article/10.1088/17551315/299/1/012020/Pdf

Sogandi, S., Mustofa, A. Z., Artika, I. M., \& Bugi, R. B. (2015). Inhibitory activity of Lactobacillus plantarum $\mathrm{U} 10$ isolated from tempoyak (fermented durian) made in Indonesia against Salmonella typhi. Microbiology Indonesia, 9(2), 73-81. doi: 10.5454/mi.9.2.4

Sogandi., Mustofa, A. Z., \& I Made, A. (2019). The characterization of bacteriocins produced by Lactobacillus plantarum strains isolated from traditional fermented foods in Indonesia and the detection of its plantaricin-encoding genes. Indonesian Journal of Biotechnology, 24(1), 1-7. doi: 10.22146/ijbiotech.42582

Stanbury, P., Whitaker, A., \& Hall, S. (2016). Principles of fermentation technology. Third Edition. Butterworth Heinemann, Oxford.

Suhendar, U., \& Sogandi, S. (2019). Identification of bioactive compounds in clove leaves (Syzygium aromaticum) extract as inhibitor streptococcus mutans (In Indonesian). Alkauniyah: Jurnal Biologi, 12(2), 229-239. doi:10.15408/kauniyah.v12i2.12251
Tamura, K., Peterson, D., Peterson, N., Stecher, G., Nei, M., \& Kumar. (2011). MEGA 5: Molecular evolutionary genetics analysis using maximum likelihood, evolutionary distance, and maximum parsimony methods. Molecular Biology Evolution, 28(10), 2731-2739. doi: 10.1093/molbev/msr121

Wang, P., Kong, F., Wei, J., Wang, Y., Wang, W., Hong, K., \& Zhu, W. (2014). Alkaloids from the mangrove-derived actinomycetes Jishengella endophytica 161111. Marine Drugs, 12(1): 477-490. doi: 10.3390/md12010477.5.21982208.2002

Yulia, R., \& Wijaya, I. S. (2015). Antioxidant compounds of methanolic extract of soybean (Glycine max (L) Merill) detam 1 variety from ultrasound extraction method (In Indonesian). Jurnal Sains Farmasi \& Klinis, 2(1), 1-10 doi: 10.29208/isfk.2015.2.1.57

Zhang, Y., Yuan, Y., Pang, Y., Yu, F., Yuan, C., Wang, D., Hu, X. (2019). Phylogenetic reconstruction and divergence time estimation of blumea dc. (asteraceae: inuleae) in China based on nrDNA ITS and cpDNA trnL-F sequences. Plants, 8(210), 1-19. doi: $10.3390 /$ plants8070210

Zinniel, D. K., Lambrecht, P., Harris, B. N., Feng, Z., Kuczmarski, D., Higley, P., Ishimaru, C. A., Arunakumari, A., Barletta, R. G., \& Vidaver, A. K. (2002). Isolation and characterization of endophytic colonizing bacteria from agronomic crops and prairie plants. Applied and Environmental Microbiology, 68(5), 2198-2208. doi: 10.1128/aem.68.5.21982208.2002 